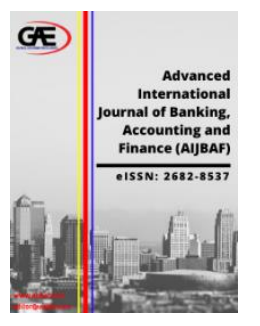

\author{
ADVANCED INTERNATIONAL JOURNAL OF \\ BANKING, ACCOUNTING AND FINANCE \\ (AIJBAF) \\ www.aijbaf.com
}

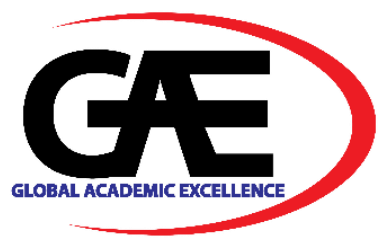

\title{
FINANCIAL DEVELOPMENT AND ECONOMIC GROWTH IN MALAYSIA FROM 1990 TO 2019: VECM APPROACH
}

\author{
Norhidayati Mohamed Zakaria ${ }^{1}$, Mohamad Yazis Ali Basah ${ }^{2 *}$ \\ 1 Graduate School of Muamalat, USIM \\ Email: hidayati_yeth@yahoo.com \\ 2 Fakulti Ekonomi dan Muamalat, USIM \\ Email: yazis@usim.edu.my \\ * Corresponding Author
}

Article Info:

Article history:

Received date: 22.07 .2021

Revised date: 11.08 .2021

Accepted date: 30.08 .2021

Published date: 01.09.2021

\section{To cite this document:}

Zakaria, N. M., \& Basah, M. Y. A. (2021). Financial Development and Economic Growth in Malaysia From 1990 to 2019: VECM Approach. Advanced International Journal of Banking, Accounting, and Finance, 3 (8), 37-54.

DOI: $10.35631 /$ AIJBAF.38004.

This work is licensed under $\underline{\mathrm{CC}} \mathrm{BY} 4.0$

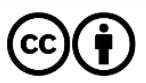

\begin{abstract}
:
Economists believe that efficient financial development is significant for building sustainable economic growth in any country. The global financial crisis, economic events and country's uniqueness has resulted in continuous research to examine the relationship of financial and economic development using numerous methods and indicators which presented various simulation that led to different views on the linkages. Most of the studies had tested the indicators individually which resulted in less dynamic findings and creates a gap in the research. Hence, this paper aims to examine the relationship between financial development and economic growth in Malaysia by observing different economic indicators concurrently. This study using Malaysia's annual time series data from 1990 to 2019. This study employs descriptive statistics, regression estimations, unit root test, Johansen co-integration test, VAR, and VECM modeling. The FTSE Kuala Lumpur Composite Index (FBMKLCI) and domestic credit as a percentage to GDP (DC) have been used as proxies for financial development while GDP per capita and Industrial Production Index (IPI) as proxies for economic growth. The findings reveal that FBMKLCI and domestic credit produces a significant relationship towards GDP per capita in the long run and short run. Contrary results found in FBMKLCI-domestic credit-IPI nexus whereby FBMKLCI and domestic credit demonstrate negative association towards IPI. As this study uses the same variables to indicates the relationship towards unalike economic growth gauge, more dynamic work and effort shall be considered to enhance the results. Government and respective institutions shall play their role effectively to revisit or formulate policy and law of the financial system to stimulate the growth of the Malaysian economy.
\end{abstract}


Keywords:

FBMKLCI, Domestic Credit, GDP Per Capita, IPI, Malaysia, VECM

\section{Introduction}

Economists believe that financial advancement is a relevant indicator to measure a rapid pace of economic growth, which has prompted ongoing research into the relationship using a variety of interventions and variables. Regardless of the fact that many countries have conducted studies on the causality between financial sector development and economic growth over the years, there are still many topics that are hotly debated. The previous studies had employed number of models by using variety of economic and finance variables. However, the analyses seldom examined economic variables simultaneously. Most of the prior research has assessed the relationship by employing Growth Domestic Product as an indicator for economic growth. While other studies examine the linkage by using Industrial Production Index to determine the economic development. As most of the previous studies had employed Growth Domestic Product and Industrial Production Index as proxies for economic development, this paper envisioned to feature the research on the connection by examining both variables concurrently and assess its causality with the credit market and capital market in Malaysia.

Technically, a country with a well-developed credit market increases capital allocation performance. A growth drive, on the opposite hand, increases the worth of the credit marketplace for participants, promotes financial development, and reinforces the initial growth impact. According to Levine et al. (2000), domestic credit as an indicator for a credit system, plays a critical role in comparison to other monetary aggregates, and it reflects the most precise role of financial proxies in steering funds for private market players. Domestic credit, as Bui (2019) points out, reflects the country's financial growth. In economics, growth is calculated by changes in production levels or the economy's gross national product, implying that the credit market and economic process are inextricably linked. The rise in GDP resulted in higher economic process. The banking sector, especially in Malaysia, incorporates a great amount of credit, as evidenced by the country's high loan-to-GDP ratio. Previous studies have paid little attention on the impact of domestic credit on economic progression. Nonetheless, domestic credit is critical in determining the country's economic growth, as evidenced by the fact that rapidly increasing domestic credit performs better than other economies (Bayoumi \& Melander, 2008).

For more than a decade, the capital market has been linked to economic development. It has a direct relationship, with good economic growth resulting in better stock results. As a result, the equity market is seen as an economic indicator in the majority of countries around the world. Levine and Zervos (1996) conducted research on equity market performance and discovered a constructive and significant partial correlation between equity market and banking development as well as GDP per capita growth. Capital market attract both domestic and foreign capitals which contribute to increasing in economic growth and foreign reserves through portfolio investment (Al-Majali \& Al-Assaf, 2014). The FBMKLCI is employed to proxy for Malaysian capital market. Since the capital market is a leading economic indicator Copyright (C) GLOBAL ACADEMIC EXCELLENCE (M) SDN BHD - All rights reserved 
Volume 3 Issue 8 (September 2021) PP. 37-54 DOI 10.35631/AIJBAF.38004

and as an indication of the broader country's growth, the influence of FBMKLCI on economic growth is crucial to examine. Numerous past studies correspondingly found that capital market development plays a pivotal role in predicting future economic growth. The significance of such research is corroborated by Nur et al., (2018), whereby they discovered a long term association between FBMKLCI and macro-economic variables such as IPI, inflation and exchange rate as well as money supply.

Industrialization is considered as a fundamental instrument for achieving a better growth of the economy and development in any nation, including Malaysia. Hence, the government continuously develop and implement policies on industrialization with the aim to build capacity as well as to generates income and employment to boost the economic performance. Strong financial system is crucial to support the constant performance in industrial activities. Recognizing the significance of industrialization in this country, the aim of this paper is to investigate its influence on the interaction between financial development and economic growth. For that matter, this paper uses IPI as it is an economic tool that measures the efficiency and wellness of industrial activities. Research in India by Patel (2012) suggest that IPI is favorable and have significant correlation with the indices. The study revealed that capital market influences IPI.

\section{Conceptual Framework}

This study's theoretical foundation is based on Joseph Schumpeter's introduction of the theory of financial development and economic growth in 1912. The argument contends that distributing national funds to businesses will promote economic development, which will be fueled by increased productivity and technical advancements. It's also interesting to note that the introduction of miniaturization in the financial sector will result in credit of creation, which will support economic activities and contribute to faster economic growth. According to Levine (1997), the financial stability depends on both banks and markets. Thus, overall system must be efficient to offer significant financial services to stimulate economic growth.

Furthermore, financial advancement is vibrant and significantly important for the development of the private sector in order to stimulate the economy and alleviate poverty problems. In terms of financial growth, the stock market and banking system are critical. Acknowledging the significant of financial development, it has been the main concern of much empirical research to explore the nexus of financial development and economic growth of the country over the years. Economic growth is an important factor in statistical indexes that are used to monitor financial progress. Such indexes are GDP, domestic credit, stock market, stock index (Bui, 2019; Basah et.al (2007) ).

The conceptual framework for this study is built on theoretical appraisals and in relation to the key ideas discussed in the literature review. Whereby the model error is $\varepsilon_{\mathrm{it}}, t$ is the time period and $i$ the number of lags. While $\alpha_{\mathrm{i}}$ is the intercept and $\beta_{1}$ and $\beta_{2}$ are the model coefficients for each variable. 


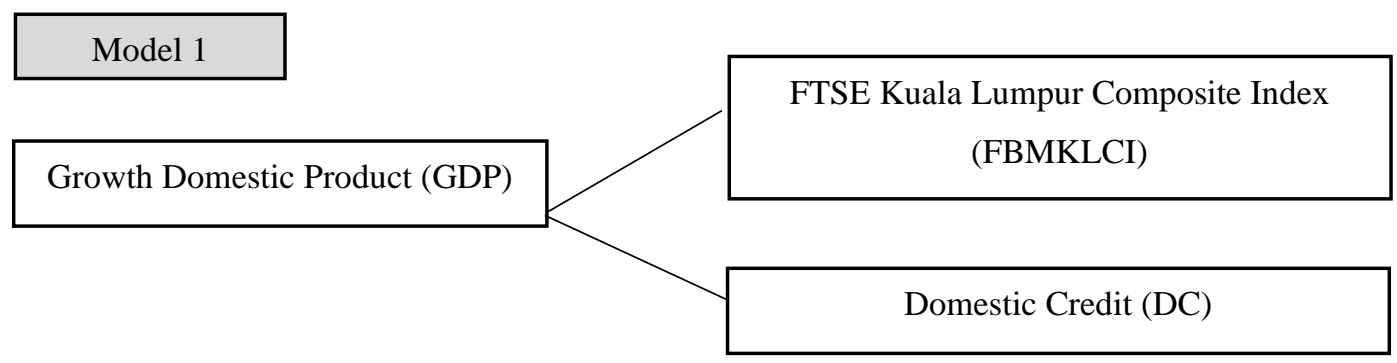

$G D P_{i t}=\alpha_{i}+\beta_{1} F B M K L C I+\beta_{2} D C+\varepsilon_{i t}$

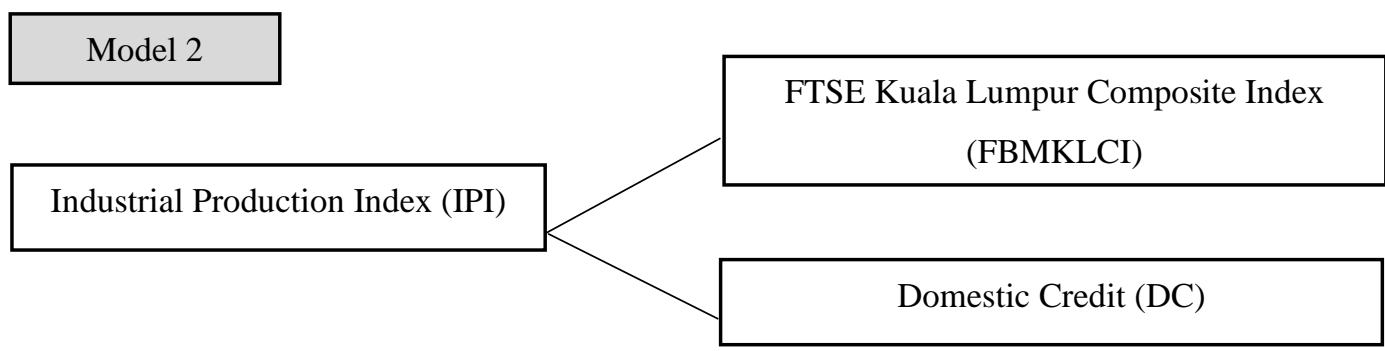

$$
I P I_{i t}=\alpha_{i}+\beta_{1} F B M K L C I+\beta_{2} D C+\varepsilon_{i t}
$$

Exploring the nexus of financial development and economic growth and recognizing the gap of the study, this paper espousing the earlier research constructs jointly and comprehensively examine, discuss the linkages of finance sector development and economic growth in Malaysia by using GDP and IPI as proxy for economic development. Furthermore, as this study employed different economic indicator to measure the country's growth, it is expected that this paper will be able to determine which indicator reflect the most important effect on economic growth, as well as provide better scenarios to support the empirical findings.

\section{Literature Review}

\section{Theoretical Consideration On Financial Development And Economic Growth}

Based on this research topic it relates back for the work of Schumpeter in 1912 that viewing the important finance sector in foster growth of the countries. Prevalent works by Goldsmith (1969), Mckinnon (1973), Bencivenga \& Smith (1991), King and Levine (1993), Levine (1997), Levine et al. (2000) and Levine (2005), correspondingly addressing the same view of Schumpeter and suggesting that financial development have direct relationship towards economic progression. They claimed that the stability of financial sector includes banks and markets, capable to offer significant financial services to stimulate the growth of economy. Voluminous of the prior studies were undertaken to examine the relationship concerning financial and economic development and mostly conducted based on either utilizing crosssection data or using time series data. The outcomes vary depending on the methods used by the researchers. It's worth noting that the results are different depending on the country or case in dispute. The results of time series studies differ depending on the date and sample used, as well as the global event and economic climate that the sample encountered. 
Volume 3 Issue 8 (September 2021) PP. 37-54 DOI 10.35631/AIJBAF.38004

Study by King and Levine (1993), whereby applied cross-section and had taking into consideration biases and specific effect in the sampling framework agree that financial development have direct relationship towards economic growth. Previous work of Neusser and Kugler (1998) in OECD countries, discovered the long-term relationship between financial development and economic growth, GDP for manufacturing sector in those countries. Bui (2019), who used a Granger causality test and a co-integration methodology to investigate the financial development-economic growth nexus by looking at the impact of domestic credit and stock market liquidity on GDP growth and GDP per capita on Vietnam economic growth, discovered that domestic credit and stock market liquidity have significantly positive relationship with the country's economic growth. Fascinating work by Shan et al.(2001) covering OECD countries and China suggest the association of financial improvement and economic growth depending on country's economic condition. Furthermore, there is great work that has been done by Jobarteh \& Ergec (2017) whereby the paper study on financial development-economic growth in the context of Islamic finance. The study covered the years 2005 to 2015 and used econometrics methods such as unit root, co-integration, and Grangercausality in the VECM framework to discover that Turkey's Islamic finance production has a unidirectional short term and long run causality to economic growth.

In Malaysia perspective, Noor \& Ramli (2017) conducted research to see if growth response is influenced by finance or if finance is influenced by growth. The Bounds ARDL test has been applied to estimate the correlation between domestic credit as a proxy for financial development and GDP per capita as proxy for economic. The study found that economic development granger causes financial development thus, recommend for proper and suitable policies must be implemented to promote great development in economy. Prior research by Amiruddin et al.(2007), described that financial development and economic growth had a short and long term complex relationship. This research had studied the relationship by utilizing the VAR method, which included Johansen co-integration, VECM, IRF, and VDC.

Following up on previous theoretical studies conducted by researchers in a variety of countries and over time, the findings mainly point to the value of financial system and institutions advancement, which has a direct and important connection with economic progression. The significant link between financial development and economic growth drives and motivates policymakers to concentrate on and have effective ways and strategies to further improve the relationship.

\section{Empirical Evidence: Analyzed Variables}

\section{Gross Domestic Product (GDP)}

GDP is an estimation of the complete worth of all occupants delivering units in a country during a particular period before deducting recompenses for fixed capital utilization. The gross domestic product can be considered by utilizing three methodologies namely production approach refers to the sum of value added, expenditure approach refers to the sum of final expenditure and income approach refers to the sum of incomes distributed by resident producer unit. In other definitions, GDP comprises all of an individual's consumption, government spending, net exports, and capital accumulation. (Vaghefi et al., 2015).

The procedures in calculating the GDP is standardized and acceptable globally had enable the comparison between countries to be made effectually. Hence using GDP is an advantage. Copyright $\odot$ GLOBAL ACADEMIC EXCELLENCE (M) SDN BHD - All rights reserved 
Volume 3 Issue 8 (September 2021) PP. $37-54$ DOI 10.35631/AIJBAF.38004

However, GDP unable to measure a number of things, for instance citizen's well-being, standard of living and happiness (Wesselink et al., 2007). Though GDP possesses weaknesses, GDP is crucial in outlining country's economy policy and World Bank Group even had suggest that GDP is an indicator which objectively able to indicates the country's economic condition, size and strength. Studies by Law et al.(2018) and Camba \& Camba (2020) had employed GDP per capita to determine growth rate of the country's economy. It is significant to highlight that, GDP per capita has weak co-integration with domestic credit and stock market as proxies for financial development (Camba \& Camba, 2020). This paper uses Philippines as subject of study.

In today's business world, policymakers and economists often use GDP per capita as a unit to represent a country's development, mixing economic prosperity and societal well-being, indicating policies that result in economic growth are seen as beneficial to society. As a result, GDP per capita is now widely used as a measure of economic development. Hence, this study employed GDP per capita as proxy for Malaysia economic growth.

\section{Industrial Production Index (IPI)}

The Industrial Production Index is a measure of the rate of change in the production of industrial commodities in real terms over time for various sectors namely manufacturing, mining and electricity. It is measured based on volume changes in production. In other word, this IPI are the overall index from the index of manufacturing, mining and electricity. A critical examination of industrial sector warrants the use of IPI. IPI give the overview of the current trend of industrial activities of any countries and used for economic analysis. In Malaysia context, country's spectacular growth has been largely driven by industrial progress. Abundant of resource in this country generates and leads to sustainable growth in the industrial production. Malaysia's industrial growth was initiated in 1990 by the Industrial Masterplan, which came into effect in 1986. The industrial output served as the pillar of economic growth and that industrialization has taken center stage in the economy of the world. Hence, in this respective paper, it is also important to account for the effects of industrial development.

Great and steady developments in industrial production offer better economic performance otherwise, the unfavorable developments in industrial production may adversely affect the economic growth. Felix Nwaolisa \& Chijindu (2016) mentioned that IPI is commonly used as a metric for real economic activity and it has been shown in theory that industrial output rises during economic growth and declines during recessions. A shift in industrial output demonstrates a shift in the economy, according to this phenomenon. Research conducted by Humpe \& Macmillan (2009) found that IPI has positive association with stock prices. According to Wongbangpo \& Sharma (2002) industrial output can be used as a proxy for the levels of economic activity that influence prices through their effect on corporate profitability. Another study by Nishat \& Shaheen (2004) mentioned that industrial production is significantly affects macroeconomic variables as increase in IPI cause upsurge the production rate in industrial sector which cause profit intensification particularly in the corporations and industries as a whole.

According to previous research, IPI has a direct relationship with the stock market, which encourages stronger market performance and leads to substantial economic growth. Although the studies did not explicitly address the effect of IPI on economic growth, they did highlight 
Volume 3 Issue 8 (September 2021) PP. 37-54 DOI 10.35631/AIJBAF.38004

the role of IPI in influencing the country's growth. Hence, supports the constructs of IPI as substantial in describing its relationship with Malaysia economic growth.

\section{FTSE Bursa Malaysia Kuala Lumpur Composite Index (FBMKLCI)}

The equity market in this country is denoted by the Kuala Lumpur Composite Index. The Kuala Lumpur Composite Index is a capitalization-weighted stock market index that was introduced in 1986. Currently, this index recognized as FTSE Bursa Malaysia Kuala Lumpur Composite Index, and it offers global significance and scope. Furthermore, the FBMKLCI, as a market barometer comprised of primary market movers, would better characterize market activities while remaining indicative of the Malaysian stock market. For a more accurate representation of the market, the FBMKLCI calculation approach usually emphasizes free float and liquidity screens. Because of its smaller basket, the FBMKLCI is easier to handle and more appealing for the production of Index Linked Products (ILPs) to encourage market liquidity. Aside from that, it is rising the frequency of index calculation from every 60 seconds to every 15 seconds in order to effectively and efficiently monitor the business pulse (Malaysia, 2015).

According to Caporale et al. (2011), equity market and economic development in CEEC countries shows substantial connection (Czech Republic, Hungary, and Poland) from 1996 to 2011. In this analysis, the VAR-GARCH method was employed. Study by Mohtadi and Agarwal (2001) also found the same result whereby, there is a direct connection between stock market and economic growth for 21 emerging markets over a 21-year span. However, according to Wang \& Ajit (2013) that used a unit root and co-integration method to examine the relationship between equity market development and economic growth in China from 1996 to 2011 suggest that there is a negative association between stock market and total market capitalization as a proxy for economic growth.

\section{Domestic Credit (DC)}

Domestic credit is a strong predictor of a country's financial growth. Schumpeter claimed that domestic credit plays an important role in driving economic growth by providing funding for investment and manufacturing. Domestic credit has a favorable relationship, positive linkage with economic development, according to the majority of studies. In a previous analysis of the Turkish economy, Kar \& Pentecost (2000) discovered that there is a causality and connection between economic growth and financial development, implying that growth precedes financial development. As the representations for financial growth, the study uses deposit of the bank, private sector's credit, and domestic credit ratios. Iqbal et al. (2012) believe that credit to the private sector in Pakistan has a substantial long-term and short-term effect on economic development. The ARDL method and VECM were used to analyze the influence of financial development and economic growth. Similarly Ben Jedidia et al.(2014) using Tunisia as a case study, demonstrate that domestic credit to the private sector has a positive impact on economic development. Domestic credit has a major impact on economic development in the Economic Community of West African States, according to Abubakar et al. (2015). C. Wang et al. (2019) confirmed the view that domestic credit has a direct and optimistic relationship with economic growth in their study of the Beijing-Tianjin-Heibei area in China, which spanned the years 2007 to 2016.

However, other scholars have argued that domestic credit is negligible and can negatively influence economic growth. Levine mentioned that the excessive growth and inappropriate use of domestic credit could lead to the credit boom in the short term and the negative effect on 
Volume 3 Issue 8 (September 2021) PP. $37-54$

DOI 10.35631/AIJBAF.38004

economic growth in the long run. Rana and Barua (2015) had conducted a research using Panel Data to examine the relationship of financial improvement and economic development for South Asian Countries (Bangladesh, Nepal, India, Pakistan and Sri Lanka) for the period 1974 to 2012 concludes that, domestic credit have no substantial impact on countries' economic advancement. Marco Pagano et al. (2012), conducted research on OECD countries from 1970 to 2003 and found that excessive increases in domestic credit is insignificant to economic growth, which is consistent with Cournede \& Denk (2015) that highlighted the negative association between domestic credit and economic growth among OECD and G20 countries. The study by Krishnankutty (2011) on North East India banks credit and economic growth using panel data covering period 1999 to 2007 found that banks credit does not influence North East India economic growth. The debates continue because previous studies have differing perspectives on the impact of domestic credit on economic progression. As a result, this research study on the relationship between domestic credit and economic growth in Malaysia aims to broaden the framework and provide a diverse range of academic perspectives.

\section{Bibliometric Review Of The Financial Development And Economic Growth}

Bibliometric is the utilization of statistical methods to analyze books, articles and other publications. The co-citation analysis was carried out for the purpose of the research to determine the fundamental literatures of study area, and a keywords co-occurrence analysis was also carried out to ascertain the theoretical framework and research themes of the study area. The bibliometric research was done using VOSviewer software. To demonstrate the increase in the literature, the first step was to construct a chart showing the growth in the number of published papers each year. Then, the review of the most relevant articles, accompanied by the co-citation analysis to classify the key documents. Finally, a co-word analysis was performed to classify the main research themes, along with an examination of the primary aspects of the keyword network structure and the evolution of the research interest.

Numerous researches have been conducted by using a variety of metrics, continents, and years. There are 869 articles published by various journals within the period of 21 years of observation until the time this paper was written. The highest number of article was in 2020 with 125 articles and the fewer paper publications were in 2000 and 2001 with only 3 papers. The global economy's complexity and major events may pique researchers' interest in continuing to investigate the nexus of financial and economic growth. This can also be seen in the examination of the countries that were used as study subjects. The article is organized by nation or territory and it was found that the papers debating on financial development and economic progression were mainly centered in the United States, with 137 articles. In the case of Malaysia, there were 66 articles discussing the subject, indicating a large number of studies.

The graphic visual mapping of the articles reports on financial development and economic growth in order to discuss the implications of the meta-analysis described earlier. Co-citation was chosen as the form of analysis and cited references as the unit of analysis to construct the map. To link co-citations with other cited sources, a threshold of 20 citations was set. Only the article with the highest total connection intensity is ranked first in terms of the number of citations. The results demonstrate the most cited article is entitled "Financial Development and Economic Growth: views and agenda" Levine (1997). The second highest citation is article entitled "Financial Intermediation and Growth: causality and causes" Levine et al. (2000). Followed by article entitled "Finance and Growth: Schumpeter might be right" King \& Levine (1993). 
Several keywords related to financial development and economic growth appeared regularly in papers over the course of the 21-year study period. Figure 1 shows the result of bibliometric keywords. The keywords in the four main clusters showed how they related to each other. The big colored boxes indicate the keywords that appear the most. As a result, the well-known keywords demonstrate the researchers' keen interest in researching the association of financial and economic growth based on a variety of indicators.

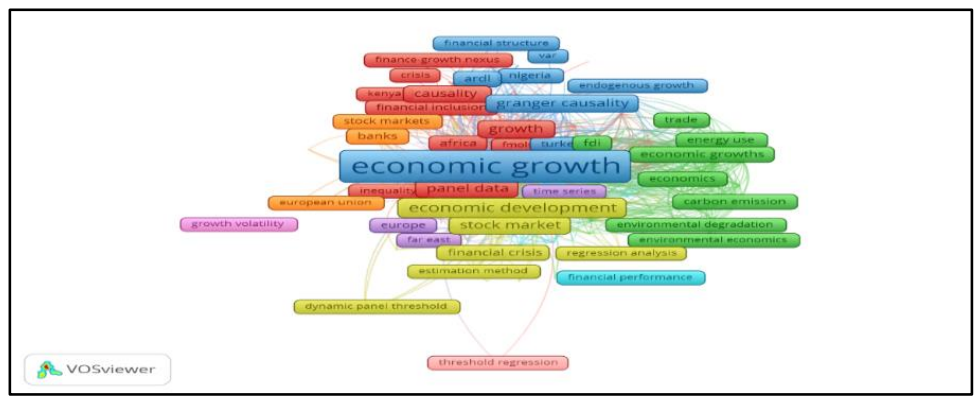

Figure 1: Bibliometric Keyword

According to the bibliometric review, there has been a large amount of research done over the years to study the relationship between financial development and economic growth. A variety of variables, indicators, and models were used, resulting in a wide range of study findings as represented by the keywords found in the analysis. However, the utmost important point to highlight here is that, the most developed countries constantly assess the impact of financial progression on economic development in order to monitor the effects and make appropriate adjustments to their economic policies to ensure stability and high growing in economy. As a result, it denotes that rapid financial development will result in rapid economic growth.

\section{Methodology}

\section{Data}

For this study, the annual time series data for GDP per capita, Industrial Production Index, as well as domestic credit of private sector as percentage of GDP were gathered from International Financial Statistics issued by the International Monetary Fund (IMF), as well as data from the Department of Statistics Malaysia website. Whereas, the Investing.com provided the data for the FTSE Kuala Lumpur Composite Index. The information gathered spans the years 1990 to 2019, with a total of 30 observations. Eviews, a data analysis method, is employed to import the time series data. Table below shows a list of the variables used in this study.

\section{Model Specification}

This corresponding research established two models to assess the causality of financial advancement and economic development, with financial advancement indicated by the same identical variables in both models. The constructs of this models are based on Levine (1997), Bui (2019), Greenwood \& Jovanic (1990) and Pradhan et al. (2014). Some indicators, that is to say GDP, domestic credit, the stock market, and the banking sector are important in assessing the impact of the development in financial systems and institutions on the growth of economy. According to the studies, financial stability is dependent on both banks and markets whereby financial services that are efficient lead to stable economic growth. The markets refer to credit 
Volume 3 Issue 8 (September 2021) PP. 37-54 DOI 10.35631/AIJBAF.38004

and capital markets hence, motivated this research to explore the influence of Malaysia's credit and capital markets on economic growth. A functional form model is constructed as:

$$
\begin{aligned}
& \mathrm{GDP}_{\mathrm{t}}=\mathrm{f}\left(\mathrm{FBMKLCI}_{\mathrm{t}}, \mathrm{DC}_{\mathrm{t}}\right) \\
& \mathrm{IPI}_{\mathrm{t}}=\mathrm{f}\left(\mathrm{FBMKLCI}_{\mathrm{t}}, \mathrm{DC}_{\mathrm{t}}\right)
\end{aligned}
$$

By including a drift parameter, the slop of each explanatory variable, and a stochastic error term, the functional equation 1 was transformed into an econometric model. As a result, the financial advancement's effect on the growth of economy can be expressed as follows:

$$
\begin{aligned}
& \mathrm{GDP}_{i t}=\alpha_{\mathrm{i}}+\beta_{1} \mathrm{FBMKLCI}_{\mathrm{t}}+\beta_{2} \mathrm{DC}_{\mathrm{t}}+\varepsilon_{\mathrm{it}} \\
& \mathrm{IPI}_{\mathrm{it}}=\alpha_{\mathrm{i}}+\beta_{1} \mathrm{FBMKLCI}_{\mathrm{t}}+\beta_{2} \mathrm{DC}_{\mathrm{t}}+\varepsilon_{\mathrm{it}}
\end{aligned}
$$

This research will be carried out in a quantitative manner and employ a comprehensive set of econometric measures for its empirical research. Three tests are used in diagnostic checking: normality (Jarque-Bera) test, heteroscedasticity (Breush-Pagan-Godfrey) test and multicollinearity test. Then come the stationary assessment, the co-integration test, the VAR and VECM.

\section{Results and Discussion}

Model 1: $G D P_{i t}=\alpha_{i}+\beta_{1} F B M K L C I+\beta_{2} D C+\varepsilon_{i t}$

\section{Descriptive Statistics}

Descriptive analysis for Model 1 demonstrates that GDP exhibiting highest degree of volatility while DC exhibited lowest degree of variation. Measuring the symmetry of the series through skewness coefficient depicted that GDP and FBMKLCI were positively skewed but the DC is vice versa. According to the Jarque-Bera statistics, all of the series are normally distributed.

\section{OLS Estimation}

Since the P-value is less than 5\%, FBMKLCI has a major effect on GDP. The coefficient shows that for every $1 \%$ increase in the FBMKLCI, the GDP increases by $23.17 \%$. The DC, on the other hand, is insignificant at $0.72 \%$. The R-squared of 0.72 shows that FBMKLCI variations account for $72 \%$ of GDP variance. The model or the combined impact of the FBMKLCI and DC against GDP is reliable as the F-statistic value is less than 0.05. This model has a Durbin Watson of 0.95 , indicating that it has positive autocorrelation. This model is fit and acceptable. Therefore, constructed model can be used to further analyze the relationship between financial development and economic growth by utilizing those particular variables.

\section{Diagnostic Test On Normality, Heteroscedasticity And Multicollinearity}

The value of Jarque-Bera in Model 1 is 1.47 can be inferred that the residual of the tests accepts the normal as the P-value is less than 5\%. The Obs* R-squared for Model 1 is 0.93 which the value is greater than 0.05 while the P-value is 0.63 . Thus, cannot reject the null means the residual are homoscedastic which makes the model fit. Detection of multicollinearity need to find the VIF which is one (1). If the value is increasing, the independent variables suffered multicollinearity. The minimum value of VIF is one as it indicates the multicollinearity does not exist. For that reason, this study assumes that multicollinearity for this regression model is 
Volume 3 Issue 8 (September 2021) PP. 37-54

DOI 10.35631/AIJBAF.38004

not severe, thus removals do not apply in the model rather leave the model alone and the model is reliable.

Model 2: IPI $_{i t}=\alpha_{i}+\beta_{1} F B M K L C I+\beta_{2} D C+\varepsilon_{i t}$

\section{Descriptive Statistics}

The FBMKLCI exhibiting highest degree of volatility and IPI exhibited lowest degree of variation. The symmetry series shows that IPI and DC demonstrated negatively skewed while the FBMKLCI depicted positively skewed. All of the series are normally distributed which consistent with the value of Jarque-Bera statistics.

\section{OLS Estimation}

The OLS result suggests that FBMKLCI has a momentous effect on IPI. The P-value is $0.54 \%$ thus the DC is insignificant. Hence, the coefficient shows that as FBMKLCI rises by $1 \%$, the IPI significantly increase by 0.05 percent. The R-squared for Model 2 is slightly lower as compared to Model 1. Its value 0.52 indicates that merely $52 \%$ of the variation in IPI is explained by FBMKLCI. However, the F-statistic value less than 0.05 represents that this model is fit and significant. The Durbin Watson is 0.45 portrays positive autocorrelation.

\section{Diagnostic Test On Normality, Heteroscedasticity And Multicollinearity}

Based on the Jarque-Bera value in Model 2 (1.02), it can be deduced that the residual of the tests accepts the normal because the P-value is less than $5 \%$. This study continued to investigate heteroscedasticity whereby the Breusch-Pagan-Godfrey theorem shows that the residuals obtained are not heteroscedastic. The Obs* R-squared for Model 2 (3.32), with a P-value of 0.20 , which is greater than 0.05 . The outcome reflects that the null hypothesis cannot be rejected; rather, accepting the null hypothesis indicates that the residuals are homoscedastic, which allows the model to fit. VIF has a minimum value of one, indicating that multicollinearity does not exist. As a result, there is no multicollinearity because the VIF value for the model is one. The result is the same as in Model 1. Thus, this study presumes that multicollinearity is not severe, so removals are also not used in the model; instead, the model is left alone and fit.

\section{Unit Root Test}

Dickey and Fuller's unit root test is used in this analysis. The results of the $t$-statistics of GDP (3.10), DC (5.30) with the P-values also less than 5\% indicates statistically significant. Therefore, for the series shows that GDP and DC at levels, the probabilities exceeded 5\% critical value that reject null hypothesis means all data at levels free from unit root and they are stationary. The FBMKLCI (5.60) and IIP (3.10) only stationary at first difference whereby the value FBMKLCI (5.60) and IIP (3.10) are greater than critical value. As the coefficient indicates that variables are not stationary at the same level, this is followed by removal procedure, in which the variables are transformed to the first difference in order to remove the non-stationary problem. 
Model 1: $G D P_{i t}=\alpha_{i}+\beta_{1} F B M K L C I+\beta_{2} D C+\varepsilon_{i t}$

\section{Co-Integration Test}

Johansen test is used to evaluate the co-integration. When tested, it is found that the probability value less than 5\% implying that there is co-integration between the variables and they absolutely move together in the long run. Both Trace-statistic and Max-Eigen-statistic demonstrates the same results at 0.05 level. Hence, confirmed the existence of long run relationship of FBMKLCI and DC on GDP in Malaysia from 1990 to 2019.

The normalized cointegrating equations GDP1-24.88KLCI1+28.68DC1 indicates that FBMKLCI has a significant and favourable impact and on GDP in the long run over time. An increase in FBMKLCI would also result in a rise in GDP. In case of DC, it is negative impact but significant which describe that an increase in DC will lead to decrease in GDP. The Johansen co-integration test proves that variables have long run association. However, this particular assessment is incapable to recognizes the direction of causality, hence this study proceeds with VECM. The VECM model is best for quantifying short and long run outcomes because ADF already shows that all variables are integrated on the same level (considering removals).

\section{Vector Autoregressive (VAR)}

This VAR framework initially looking at the long run and short run relationship of the variables via the co-integration technique. The establishment of co-integration analysis has provided an empirical approach in analysing the relationship. Thus, three regression models be tested which refers to GDP, FBMKLCI and DC respectively whereby the variables are employed to construct Model 1. This VAR estimation is the extension of stationarity outcome as tested in $\mathrm{ADF}$ and co-integration test whereby the variables have long run association and move together, thus support the decision to run this VAR model. All of the outcomes based on the same criteria lag selection which lag one at $5 \%$ level of significance as indicated by AIC.

The results show that the coefficient of determination for Model 1 whereby the value of Rsquared is 0.449 . This indicates that $45 \%$ of the total variation in GDP is explained by the explanatory variables. The value of adjusted R-squared of 0.283 shows the model fit and suggest the explanatory variables are significant in explaining dependent variable. This shows that the model is appropriate.

\section{Vector Error Correction Model (VECM)}

The variables met the pre-condition criteria, stationary at first difference, cointegrates via Johansen, VAR model being tested. As there are cointegrating vectors, vector error correction model (VECM) is applied. The VECM values for the variables are found to be co-integrated in both the short and long run. Model 1 have an error coefficient of 1.00, which ensures that the previous period's deviation from long run equilibrium is corrected by $1 \%$ in the current period. Model 1 also illustrates that, in the short run the first lagged value $24.99 \%$ change in FBMKLCI is associated in GDP on average ceteris paribus and $28.68 \%$ change in DC is associated in GDP.

The results shown below explain Model 1 short and long run causality, respectively. The cointegration is equal to the Error Correction Term (ECT), and this error correction coefficient indicates how quickly the model can return to equilibrium after a disturbance. Hence, $C$ (1) Copyright (C) GLOBAL ACADEMIC EXCELLENCE (M) SDN BHD - All rights reserved 
Volume 3 Issue 8 (September 2021) PP. $37-54$ DOI 10.35631/AIJBAF.38004

equals speed of adjustment towards long-run equilibrium. In terms of the long run coefficient, it must be in negative sign indicating the ability to bounce back to equilibrium. In case of positive sign, it indicates movement away from equilibrium. C (1) is negatively insignificant at the 5\% level for Model 1. This describes that there is long term causality running from FBMKLCI and DC to GDP. Meaning that, FBMKLCI and DC have effect on the GDP in the long term. However, the P-value is insignificant which indicates lack of adjustments towards long run equilibrium in any disequilibrium situation.

Table1: Estimation Results Model 1

\begin{tabular}{|c|c|c|c|c|}
\hline & Coefficient & Std. Error & $\mathrm{t}$-Statistic & Prob. \\
\hline $\mathrm{C}(1)$ & -0.097879 & 0.089482 & -1.093843 & 0.2884 \\
\hline $\mathrm{C}(2)$ & -0.606126 & 0.188516 & -3.215243 & 0.0048 \\
\hline$C(3)$ & -0.449432 & 0.159610 & -2.815807 & 0.0114 \\
\hline C(4) & 1.368699 & 1.770266 & 0.773160 & 0.4495 \\
\hline$C(5)$ & 0.747869 & 1.118442 & 0.668670 & 0.5122 \\
\hline$C(6)$ & 26.33213 & 26.40637 & 0.997189 & 0.3319 \\
\hline$C(7)$ & -41.44913 & 22.93452 & -1.807281 & 0.0875 \\
\hline$C(8)$ & 132.2309 & 205.4682 & 0.643559 & 0.5280 \\
\hline
\end{tabular}

Then, Wald procedure is applied for this model to study the short run causality whether the coefficients are jointly having short run causality or not. The Chi-Square and respective Pvalue for Model 1 suggest that there is no short run causality between FBMKLCI and GDP, but there is short run causality between DC and GDP.

Model 2: IPI $_{i t}=\alpha_{i}+\beta_{1} F B M K L C I+\beta_{2} D C+\varepsilon_{i t}$

\section{Co-Integration Test}

The Johansen co-integration test demonstrates the same results for both Trace-statistic and Max-Eigen-statistic at the 0.05 level, indicating that the results are consistent with Model 1. The long-term relationship between FBMKLCI and DC on IPI in Malaysia from 1990 to 2019 was confirmed. The normalized cointegrating equation IPI $\mathrm{it}_{\mathrm{it}}=\alpha_{\mathrm{i}}+\beta_{1}$ FBMKLCI $+\beta_{2} \mathrm{DC}+\varepsilon_{\mathrm{it}}$, specifies that FBMKLCI has a negative impact on IPI in the long run while DC has a positive impact. As a result, an upsurge in the FBMKLCI will result in a decrease in the IPI, whereas an increase in the DC will result in an increase in the IPI.

\section{Vector Autoregressive (VAR)}

Aligned with Model 1, this study tests three regression models, referring to IPI, FBMKLCI, and DC respectively, whereby the variables utilized to construct Model 2. All of the outcomes based on the same criteria lag selection. According to AIC, the outcomes are significant at 5\% level. The value of R-squared for Model 2 is 0.213 demonstrates that the explanatory variables able to justify and explain for only $21 \%$ of the variance in IPI. This model is less dynamic than Model 1, with the result indicating that the independent variables determine $45 \%$ of the deviation in GDP as the dependent variable. The use of the same explanatory variables to describe different dependent variables may lead to model reliability issues.

\section{Vector Error Correction Model (VECM)}


Volume 3 Issue 8 (September 2021) PP. $37-54$ DOI 10.35631/AIJBAF.38004

In both the short and long runs, the VECM values for the variables are found to be cointegrated. Model 2 has an error coefficient of 1.00, ensuring that the previous period's deviation from long run equilibrium is corrected by $1 \%$ in the current period. Model 2 also shows that a $0.76 \%$ change in FBMKLCI and a $2.32 \%$ change in DC are associated with change in IPI on average ceteris paribus. As for the short and long term causativeness of Model 2, the results show that $\mathrm{C}$ (1) is positively insignificant at the 5\% level, indicating that there is no long-term causality between FBMKLCI and DC and IPI. This implies that in the long term, the FBMKLCI and DC have no direct impact on IPI.

Table 2: Estimation Results Model 2

\begin{tabular}{lcccc}
\hline & Coefficient & Std. Error & t-Statistic & Prob. \\
\hline $\mathrm{C}(1)$ & 0.003008 & 0.018041 & 0.166729 & 0.8694 \\
$\mathrm{C}(2)$ & -0.779218 & 0.203561 & -3.827924 & 0.0012 \\
$\mathrm{C}(3)$ & -0.373288 & 0.194519 & -1.919032 & 0.0710 \\
$\mathrm{C}(4)$ & 0.010562 & 0.010394 & 1.016220 & 0.3230 \\
$\mathrm{C}(5)$ & 0.006222 & 0.006424 & 0.968558 & 0.3456 \\
$\mathrm{C}(6)$ & 0.062589 & 0.163311 & 0.383248 & 0.7060 \\
$\mathrm{C}(7)$ & -0.199527 & 0.137901 & -1.446890 & 0.1651 \\
$\mathrm{C}(8)$ & 0.039382 & 1.352647 & 0.029115 & 0.9771
\end{tabular}

The Wald procedure is then applied to Model 2. This particular test is vital to determine if the coefficients have short term association together or not. The Chi-Square and P-values of Model 2 variables, indicate that neither FBMKLCI nor DC have any short-run causality against IPI.

\section{Discussion}

The VECM approach employed in this study demonstrates that this research is significant for the overall regression coefficient where at 5\% level, the P-value of F-statistic for both models less than 0.05 meaning that the combine effect of FBMKLCI and domestic credit is substantial towards GDP and IPI. The coefficient of determination shows that Model 1 of this study is more robust and vibrant as $75 \%$ of the variation in GDP per capita can be explained by the FBMKLCI and domestic credit. While another 25\% remains unexplained, this could be due to the omission of some important variables. Meanwhile, the coefficient determination for Model 2 depicts slightly lower value than Model 1 which 52\% of the variation in IPI is described by FBMKLCI and domestic credit.

It can be determined that the FBMKLCI and domestic credit have a long-term positive and important effect on GDP. However, only domestic credit has a major nexus to GDP in the short-term, whereas the FBMKLCI is insignificant. On the other hand, this study shows that FBMKLCI and domestic credit have no short-run or long-run dynamic linkages with IPI, implying that FBMKLCI and domestic credit are insignificant and have no direct effect on IPI. Furthermore, this paper proposes that using the VECM method to research the financial development-economic growth nexus in Malaysia, GDP per capita as a proxy for economic growth represents a significant result as compared to IPI. Most of the previous studies also employed GDP as proxy for economic growth and the fact that the observations of this study produce relatively same results as past works, may be due to the universal characteristic of GDP. Calculating GDP is standardized and acceptable comprehensively had enable the practicality of the research. As World Bank Group had suggested that GDP is crucial in 
Volume 3 Issue 8 (September 2021) PP. $37-54$

DOI 10.35631/AIJBAF.38004

outlining country's economy policy and it is an indicator which empirically able to indicates the country's economic performance. In addition, this study used GDP per capita which coherent with the view that it is now commonly used as an indicator for economic growth.

\section{Limitation and Recommendation}

The findings of this analysis are based on the results of two models that were run at the same time and used similar independent variables to predict different dependent variables. The independent variables are less forceful in this analysis, which leads to unfavorable results. Despite this limitation, it's worth noting that this study adds to the empirical evidence on the relationship between financial development and economic growth, especially in the context of Malaysia, from 1990 to 2019.

Overall considering the results and limitation in this paper, there are some recommendation for future study and to respective parties in order to obtain more precise and dynamic findings. To the researcher, there are numerous variables that shall be use to evaluate the association between financial development and economic growth. More and appropriate dependent or independent variables are potentials to the researcher to get more significant result. In this paper, the same independent variables used to examine the relationship towards diverse dependent variables. Moreover, the researcher can also broaden the research scope as most of the previous works explore on conventional base. The researcher could look into the relationship between financial development and economic growth through the lens of Islamic finance. The researcher should take advantage of this opportunity because Malaysia is the undisputed pioneer in Islamic finance, and Islamic finance has made significant contributions to the country's economic development.

Other than that, examine the connection between financial development and economic growth also important to the investors. As capital market or stock market is significant and has direct association towards economic performance. Investors should use analysis to better recognize and realize the influence of equity market impact and forecast the economic performance, as changes in the economy can trigger significant changes stock prices movement and profits. As for the government and relevant institutions, the findings from the research are the appropriate references or output in order to revisit, construct or implement policies, laws and guidelines for the benefit of the country.

\section{Conclusion}

In conclusion, the VECM approach and variables used has provide clear justification and clarification on the study's objectives, research questions, and hypotheses. There are four hypotheses, two of which related to GDP are accepted and two of which associated with IPI are rejected. The answers to related research questions accept and justify the hypotheses that there are relationships between FBMKLCI-GDP and DC-GDP. Whereas the hypotheses of FBMKLCI-IPI and DC-IPI linkages are rejected and supported by the answers to the related research questions. The objectives of this study to investigate the impact of FBMKLCI and DC on the GDP and IPI growth are also well justified because all of the relationships between variables are well explained.This study outlined its limitations and made recommendations to organize some ideas for upcoming research in this specific study area. Further research on financial innovations and economic growth is necessary to gain a better understanding of the field and to improve the country's financial systems and institutions in order to stimulate a higher rate of economic growth.

Copyright $\odot$ GLOBAL ACADEMIC EXCELLENCE (M) SDN BHD - All rights reserved 


\section{References}

Abubakar, A., Kassim, S. H., \& Yusoff, M. B. (2015). Financial Development, Human Capital Accumulation and Economic Growth: Empirical Evidence from the Economic Community of West African States (ECOWAS). Procedia - Social and Behavioral Sciences, 172, 96-103. https://doi.org/10.1016/j.sbspro.2015.01.341

Al-Majali, A. A., \& Al-Assaf, G. I. (2014). Long-Run and Short-Run Relationship Between Stock Market Index and Main Macroeconomic Variables Performance in Jordan. European Scientific Journal, 1010(1010), 1857-7881.

Amiruddin, R., Nor, A. S. M., \& Ismail, I. (2007). Test for dynamic relationship between financial development and economic growth in Malaysia. In Gadjah Mada international journal .... core.ac.uk. https://core.ac.uk/download/pdf/294903214.pdf

Basah, M. Y. A., Yusuf, M. M., \& Sabri, H. (2007). Financial development and economic growth evidence from Malaysia. The Journal of Muamalat and Islamic Finance Research, 59-82.

Bayoumi, T., \& Melander, O. (2008). Credit Matters: Empirical Evidence on U.S. MacroFinancial Linkages.

Ben Jedidia, K., Boujelbène, T., \& Helali, K. (2014). Financial development and economic growth: New evidence from Tunisia. Journal of Policy Modeling, 36(5), 883-898. https://doi.org/10.1016/j.jpolmod.2014.08.002

Bencivenga, V. R., \& Smith, B. (1991). Financial Intermediation and Endogenous Growth. Review of Economic Studies, 58(2), 195-209.

Bui, T. N. (2019). The role of financial development in the vietnam economy. WSEAS Transactions on Business and Economics, 16, 471-476.

Camba, A. C., \& Camba, A. L. (2020). The dynamic relationship of domestic credit and stock market liquidity on the economic growth of the Philippines. Journal of Asian Finance, Economics and Business, 7(1), 37-46. https://doi.org/10.13106/jafeb.2020.vol7.no1.37

Caporale, G. M., Rault, C., Sova, R., \& Sova, A. (2011). Financial Development and Economic Growth: Evidence from Ten New EU Members. SSRN Electronic Journal. https://doi.org/10.2139/ssrn.1499786

Cournede, B., \& Denk, O. (2015). Finance and Economic Growth in OECD and G20 Countries. SSRN Electronic Journal, 1223. https://doi.org/10.2139/ssrn.2649935

Felix Nwaolisa, E., \& Chijindu, A. A. (2016). The Relationship between Index of Industrial Production and Stock Market Liquidity: A Co-integration Evidence from Stock Exchange of Nigeria's Value of Stock Traded Ratio. December. https://doi.org/10.20936/FAF/160104

Goldsmith, R. W. (1969). Financial Structure and Development. Yale University Press, New Haven.

Greenwood, J., \& Jovanic, B. (1990). Financial Development, Growth, and the Distribution of Income. Journal of Political Economy, 98(5), 1076-1107.

Humpe, A., \& Macmillan, P. (2009). Can Macroeconomic Variables Explain Long Term Stock Market Movements? A Comparison of the US and Japan. Applied Financial Economics, 19(2), 111-119.

Iqbal, M. Z., Ahmad, N., \& Hussain, Z. (2012). Impact of Savings and Credit on Economic Growth in Pakistan. Pakistan Journal of Social Sciences (PJSS), 32(1), 39-48.

Jobarteh, M., \& Ergec, E. H. (2017). Islamic Finance Development and Economic Growth: Empirical Evidence From Turkey. Turkish Journal of Islamic Economics, 4(1), 31-47. https://doi.org/10.15238/tujise.2017.4.1.31-47

Copyright $\odot$ GLOBAL ACADEMIC EXCELLENCE (M) SDN BHD - All rights reserved 
Kar, M., \& Pentecost, E. J. (2000). Financial development and economic growth in Turkey: further evidence on the causality issue. researchgate.net. https://www.researchgate.net/profile/Muhsin_Kar/publication/228581900_Financial_ development_and_economic_growth_in_Turkey_further_evidence_on_the_causality_ issue/links/09e41513205d1039d1000000/Financial-development-and-economicgrowth-in-Turkey-further-ev

King, R. G., \& Levine, R. (1993). Finance and growth: schumpeter might be right. Quarterly Journal of Economics, 108(3), 717-737. https://doi.org/10.2307/2118406

Krishnankutty, R. (2011). Role of Banks Credit in Economic Growth: A Study with Special Reference to North East India. Economic Research Guardian, 1(2), 60-71.

Law, S. H., Kutan, A. m., \& Naseem, N. A. . (2018). The role of institutions in finance curse: Evidence from international data. Journal of Comparative Economics, 46(1), 174-191.

Levine, R. (1997). Financial Development and Economic Growth: View and Agenda. Economic Literature, 35(2), 688-726.

Levine, R. (2005). Finance and Growth: Theory and Evidence. In P. Aghion \& S. N. Durlauf (Reds), Handbook of Economic Growth (Vol 1A, bll 865-934). https://doi.org/10.1016/S1574-0684(05)01012-9

Levine, R., Loayza, N., \& Beck, T. (2000). Financial Intermediation and Growth : Causality and Causes. Journal of Monetary Economics, 46(1), 31-77.

Levine, R., \& Zervos, S. (1996). Stock market development and long-run growth. The World Bank Economic Review, 10, 323-339.

Malaysia, B. (2015). FTSE Bursa Malaysia KLCI. In Group (Number October, bll 1-4).

Marco Pagano, Pica, G., Beck, T., \& Kramarz, F. (2012). Finance and employment. Economic Policy, 27(69), 7-55.

Mckinnon, R. I. (1973). Money and Capital in Economic Development. The Brookings Institution, Washington, D.C.

Neusser, K., \& Kugler, M. (1998). Manufacturing growth and financial development: Evidence from OECDcountries. Review of Economics and Statistics, 80(4), 638-646. https://doi.org/10.1162/003465398557726

Nishat, M., \& Shaheen, R. (2004). Macroeconomic factors and the Pakistani equity market. Pakistan Development Review, 43(4 II), 619-636. https://doi.org/10.30541/v43i4iipp.619-637

Noor, S. I. M., \& Ramli, N. R. (2017). Financial Growth and Economic Development: Evidence from Malaysia. International Journal of Academic Research in Business and Social Sciences, 7(10), 457-466. https://doi.org/10.6007/ijarbss/v7-i10/3393

Nur, H., Hamidi, A., Khalid, N., \& Karim, Z. A. (2018). Revisiting Relationship Between Malaysian Stock Market Index and Selected Macroeconomic Variables Using Asymmetric Cointegration (Mengkaji Semula Hubungan Antara Indeks Pasaran Saham Malaysia dan Pembolehubah Makroekonomi Menggunakan Kointegrasi Asimetri). Jurnal Ekonomi Malaysia, 52(1), 311-319. http://dx.doi.org/10.17576/JEM-20185201-25

Patel, S. (2012). The effect of Macroeconomic Determinants on the Performance of the Indian Stock Market. Management Review Journal, 22, 117-127. https://doi.org/10.1049/em:19940108

Pradhan, R. P., Arvin, M. B., Hall, J. H., \& Bahmani, S. (2014). Causal nexus between economic growth, banking sector development, stock market development, and other 
Volume 3 Issue 8 (September 2021) PP. 37-54 DOI 10.35631/AIJBAF.38004

macroeconomic variables: The case of ASEAN countries. Review of financial economics, 23(4), 155-173.

Rana, R. H., \& Barua, S. (2015). Financial Development and Economic Growth: Evidence from a Panel Study on South Asian Countries. Asian Economic and Financial Review, 5(10), 1159-1173. https://doi.org/10.18488/journal.aefr/2015.5.10/102.10.1159.1173

Shan, J. Z., Morris, A. G., \& Sun, F. (2001). Financial Development and Economic Growth: An Egg-and-Chicken Problem. Review of International Economics, 9(3), 443-454.

Vaghefi, N., Siwar, C., \& Aziz, S. (2015). Green GDP and Sustainable Development in Malaysia. Current World Environment, 10(1), 01-08. https://doi.org/10.12944/cwe.10.1.01

Wang, B., \& Ajit, D. (2013). Stock market and economic growth in China. Economics Bulletin, 33(1), 95-103.

Wang, C., Zhang, X., Ghadimi, P., Liu, Q., Lim, M. K., \& Stanley, H. E. (2019). The impact of regional financial development on economic growth in Beijing-Tianjin-Hebei region: A spatial econometric analysis. physica A: Statistical Mechanics and Its Applications, 521, 635-648.

Wesselink, B., Bakkes, J., Best, A., Hinterberger, F., \& Brink, P. ten. (2007). Beyond GDP: Measuring progress, true wealth, and the well-being of nations. Measurement Beyond GDP,304.https://ec.europa.eu/environment/beyond_gdp/proceedings/bgdp_proceedin gs_full.pdf

Wongbangpo, P., \& Sharma, S. C. (2002). Stock market and macroeconomic fundamental dynamic interactions: ASEAN-5 countries. Journal of Asian Economics, 13(1), 27-51. 